\title{
Biosorption of $\mathrm{Cd}^{+2}, \mathrm{Cu}^{+2}$, and $\mathrm{Ni}^{+2}$ Ions by a Thermophilic Haloalkalitolerant Bacterial Strain (KG9) Immobilized on Amberlite XAD-4
}

\author{
Hüseyin Alkan*, Reyhan Gul-Guven², Kemal Guven³, Sait Erdogan, Mehmet Dogru² \\ 'Biochemistry Department, Faculty of Pharmacy \\ ${ }^{2}$ Science Teaching Department, Ziya Gökalp Education Faculty \\ ${ }^{3}$ Biology Department, Faculty of Science \\ ${ }^{4}$ Chemistry Department, Faculty of Science \\ Dicle University, 21280 Diyarbakir, Turkey \\ Received: January 7, 2015 \\ Accepted: May 14, 2015
}

\begin{abstract}
A newly isolated thermophilic haloalkalitolerant bacterial strain (KG9) as immobilized cells on a solid support was presented as a new biosorbent for the enrichment of $\mathrm{Cd}(\mathrm{II}), \mathrm{Cu}$ (II), and $\mathrm{Ni}$ (II) prior to flame atomic absorption spectrometric analysis. The KG9 strain was identified as a close member of Bacillus licheniformis following complete sequencing of $16 \mathrm{~S}$ rRNA. The optimum conditions such as $\mathrm{pH}$, amount of adsorbent, eluent type and volume, flow rate of sample solution, volume of sample solution, and matrix interference effect on the retention of the metal ions were evaluated for the quantitative recovery of the analytes. The analyte ions were quantitatively recovered and desorbed at $\mathrm{pH}$ range of $6.0-7.0$ and $5 \mathrm{~mL}$ of $0.5 \mathrm{~mol} \cdot \mathrm{L}^{-1} \mathrm{HCl}$. The loading capacities of adsorbents for $\mathrm{Cd}(\mathrm{II}), \mathrm{Cu}(\mathrm{II})$, and $\mathrm{Ni}(\mathrm{II})$ were found to be $22.7,61.1$, and $33.4 \mu \mathrm{mol} \cdot \mathrm{g}^{-1}$, respectively. The analytical detection limits for cadmium(II), copper(II), and nickel(II) were $0.42 \mu \mathrm{g} \cdot \mathrm{L}^{-1}, 0.54 \mu \mathrm{g} \cdot \mathrm{L}^{-1}$, and $1.24 \mu \mathrm{g} \cdot \mathrm{L}^{-1}$. The proposed procedure was applied for the determination of metal ions in river water, drinking water, and mushrooms. The accuracy of the developed procedure was tested by analyzing NRCC-SLRS4 riverine water and SRM1570a spinach leaves as the certified reference materials.
\end{abstract}

Keywords: heavy metal biosorption, thermophilic haloalkalitolerant Bacillus licheniformis KG9, preconcentration, FAAS, Amberlite XAD-4

\section{Introduction}

Direct analysis of trace levels of metal ions in environmental and biological samples is rather difficult using conventional analytical techniques such as flame atomic absorption spectrometry (FAAS) because of very low concentrations of these metal ions and matrix interferences $[1,2]$. However, this technique also presents desirable characteristics such as operational facilities, good selectivity, and low

*e-mail: mhalkan@dicle.edu.tr cost. In spite of high sensitivities obtained by ICP-OES and ICP-MS, these techniques are relatively expensive and present limitations related to the concomitants such as high dissolved solid contents of samples [3, 4]. Therefore, sample preconcentration is becoming an essential treatment step before flame atomic absorption determination $[5,6]$.

The widely used analytical techniques for the separation and preconcentration of metal ions include solid-phase extraction [7-12], liquid-liquid extraction [13, 14], coprecipitation [15], ion-exchange [16, 17], and chelating resins [18]. Solid-phase extraction of heavy metal ions for pre- 
concentration is commonly preferred to in other techniques due to high sensitivity and easy methodology. Various adsorbents including some inorganic, organic, and biological adsorbents have been used for the preconcentration traces of heavy metal ions. The use of biological materials for effective removal and preconcentration of heavy metals from contaminated waters has emerged as a potential alternative method to conventional treatment techniques. Of all the preconcentration methods, biosorption by microorganisms immobilized on solid support seems to be the most effective preconcentration methods [5, 19-23].

Biosorption is a term that usually describes the removal of heavy metals from an aqueous solution through their passive binding to a biomass [24-26]. Bacteria [5, 26, 27], yeast [24], algae [28], and fungi [29] are biological microorganisms that have been immobilized and employed as sorbents in the biosorption process. It is well known that the cell wall constituents of microorganisms play an important role in metal sequestering. The cell walls of microbial biomass contain proteins, polysaccharides, cellulose, glucan, lipids, and chitin. These characteristics turn the biosorption into an ideal process to be introduced in solid phase extraction systems for analytical approaches [19, 24, 30].

Natural and synthetic sorbents such as sepiolite [31], silica gel [32], chitosan [33], alginate [34], cellulose [35, 36], and Amberlite XAD resins have been mostly used as support material for the immobilization of microbial cells. Particularly Amberlite XAD resins are widely used for preconcentration procedures because of their good physical and chemical properties, such as porosity, high surface area, durability, and purity [5, 37].

Several studies have looked at the difficulty of determining heavy metals such as cadmium, nickel, and copper using only FAAS, which suggests the use of microorganisms immobilized on synthetic resins such as XAD-4 for preconcentration and determination of heavy metals in various samples $[2,5,25,29]$. The present work proposes the use of a thermophilic haloalkalitolerant bacterial strain (KG9) immobilized on Amberlite XAD-4 as a new biosorbent for the determination of $\mathrm{Cd}, \mathrm{Ni}$, and $\mathrm{Cu}$ by FAAS in real samples such as the Tigris River and drinking water, as well as in wild edible mushrooms.

\section{Experimental}

\section{Instrumentation}

A Unicam AA-929 flame atomic absorption spectrometer with hollow cathode lamb and air/acetylene mixture was used for the determination of trace metals. The instrumental parameters were those recommended by the manufacturer. The wavelengths ( $\mathrm{nm}$ ) selected for the determination of the analytes were: $\mathrm{Cd} 228.8, \mathrm{Cu} 324.7$, and $\mathrm{Ni} 232.0$. A MettlerToledo MPC 227 model digital pH meter was used to adjust the $\mathrm{pH}$ of the solutions. Filtration columns $(1.0 \mathrm{~cm} \times 10.0 \mathrm{~cm})$ equipped with polypropylene frites were used for solid-phase extraction (SPE). A Watson Marlow SCI-323 model peristaltic pump was used to enable the solutions to pass through the column. A speedwave MWS3 , Berghof microwave was used for sample digestion.

\section{Reagents and Solutions}

All aqueous solutions were prepared with double-distilled water. All the chemicals used were of analytical reagent grade. Metal working solutions at $\mu \mathrm{g} \cdot \mathrm{l}^{-1}$ level were prepared daily by diluting a corresponding $1000 \mu \mathrm{g} \cdot \mathrm{ml}^{-1}$ solution (Merck). Hydrochloric and nitric acid solutions used as eluents were prepared by direct dilution with deionized water from the concentrated solutions (Merc).

Amberlite XAD-4 resin was used as a support material for the immobilization of the bacterial strain. Amberlite XAD-4 resin (with a surface area $725 \mathrm{~m}^{2} \cdot \mathrm{g}^{-1}$, pore diameter $4 \mathrm{~nm}$, and bead size 20-60 mesh) was supplied by Sigma. XAD-4 resin obtained from the supplier contained organic and inorganic impurities. The following buffer solutions were used for a preconcentration procedure: $\mathrm{Na}_{2} \mathrm{SO}_{4} /$ $\mathrm{NaHSO}_{4}$ buffer for $\mathrm{pH} 2.0$ and 4.0, $\mathrm{CH}_{3} \mathrm{COOH} / \mathrm{NaCH}_{3} \mathrm{COO}$ buffer for $\mathrm{pH} 4.0$ and 6.0 , and $\mathrm{NH}_{3} / \mathrm{NH}_{4} \mathrm{Cl}$ for $\mathrm{pH} 8.0$ and 10.0 .

\section{Microorganism and Growth Conditions}

In this study, a thermophilic haloalkalitolerant bacterial strain (KG9) isolated from a hot spring in Batman, Turkey, was immobilized on Amberlite XAD-4 as a new biosorbent in metal determination. The KG9 strain was identified as a close member of Bacillus licheniformis following complete sequencing of $16 \mathrm{~S}$ rRNA. PCR mediated amplification of the 16S rRNA and purification of the PCR products were performed at the DSMZ (Deutsche Sammlung von Mikroorganismen und Zellkulturen: German Collection of Microorganisms and Cell Cultures). The 16S rRNA resulting in a complete sequence of the KG9 strain was compared with representative sequences of organisms belonging to the Firmicutes group. The most important characteristics of this strain are both halotolerant (grown at up to $15 \%$ salt) and alkalitolerant (growth between $\mathrm{pH}$ 5-10.5) [5].

Bacillus licheniformis KG9 was grown in $1000 \mathrm{ml}$ Erlenmeyer flasks containing $200 \mathrm{ml}$ of liquid medium (NB; nutrient broth). The flasks were inoculated with $8 \mathrm{ml}$ of a cell suspension and stirred in a water bath at $120 \mathrm{rpm}$ at $50^{\circ} \mathrm{C}$ for $48 \mathrm{~h}$. After the desired growth time, the cells were harvested by centrifuge at 10,000 rpm for $10 \mathrm{~min}$.

\section{Immobilitization of the Microorganism onto Amberlite XAD-4}

The immobilization of KG9 strain on the substrate was performed as follows: $150 \mathrm{mg}$ of dry and dead bacteria powder was mixed with $1 \mathrm{~g}$ of Amberlite XAD-4. The mixture was wetted with $2 \mathrm{~mL}$ of doubly distilled water and thoroughly mixed. The amount of bacteria taken up by the resin was determined by measuring the increase in the weight of the resin after mixing the paste, which was heated in an oven at about $105^{\circ} \mathrm{C}$ for $1 \mathrm{~h}$ to dry the mixture. The wetting and drying steps were repeated to maximize 
the contact between KG9 strain and Amberlite XAD-4, thereby improving immobilitization efficiency. Then, the product obtained was ground to original size (20-60 mesh) and used as an adsorbent.

\section{Preparation of the Column}

Column procedures are usually less time-consuming and allow easier regeneration of the biosorbent. The KG9immobilized resin $(300 \mathrm{mg})$ was wetted with $5 \mathrm{~mL}$ of distilled water. The mixture was transferred to a $1.0 \mathrm{~cm} \times 10.0$ $\mathrm{cm}$ polyethylene column. Before use, $0.5 \mathrm{~mol} \cdot \mathrm{L}^{-1} \mathrm{HCl}$ solution and doubly distilled deionized water were passed through the column in order to condition and clean it. Then the column was conditioned to the studied $\mathrm{pH}$ by passing a buffer solution providing the same $\mathrm{pH}$ as that of the sample solution through the column, prior to passage of the sample solution. The experiments were conducted by pumping a metal solution in down-flow mode through the column with a peristaltic pump. The effluents were collected fractionally and analyzed using AAS.

\section{General Procedure for Sorption Studies}

The method was tested with model solution before its application to real samples. Metal solutions containing $10 \mu \mathrm{g}$ of $\mathrm{Cu}$ (II), $\mathrm{Cd}(\mathrm{II})$, and $\mathrm{Ni}$ (II) in $100 \mathrm{~mL}$ was taken and the $\mathrm{pH}$ was adjusted to the optimal value with buffer solution. The minicolumn was preconditioned by passing buffer solution at the working $\mathrm{pH}$. The resulting solution was passed through the column by a flow rate adjusted to the optimal value. After passing the solution completely, the column was rinsed twice with $10 \mathrm{~mL}$ of distilled water. The adsorbed metal on the biosorbent was eluted with by $0.5 \mathrm{~mol} \cdot \mathrm{L}^{-1} \mathrm{HCl}$ solution. The metal concentrations in the eluent solution were determined by flame atomic absorption spectrometry.

KG9-immobilized resin was used repeatedly after washing with $0.5 \mathrm{~mol} \cdot \mathrm{L}^{-1} \mathrm{HCl}$ solution and then doubly distilled water.

\section{Preparation of Samples}

The proposed method was applied to solid/liquid samples. The water samples were collected from the Tigris River and drinking water from the city of Diyarbakır. The polyethylene bottles (2L) used for sampling river water and drinking water were successively precleaned with detergent, doubledeionized distilled water, dilute $\mathrm{HNO}_{3}$, and double-deionized distilled water. High-purity $\mathrm{HNO}_{3}(10 \mathrm{~mL})$ was added to keep the final acidity of the water at about $\mathrm{pH} 2$ after sampling, in order to prevent adsorption of the metal ions on the bottle walls. The samples, including NRCC-SLRS-4 riverine water, were filtered through a Milipore cellulose membrane with pore size $0.45 \mu \mathrm{m}$ immediately after sampling and stored at $4^{\circ} \mathrm{C}$. Mushroom sample (L.deliciosus - a wild edible mushroom species in southwest Anatolia, Turkey) was dried at $80^{\circ} \mathrm{C}$ for $24 \mathrm{~h}$ and then ground in an agat mortar.

Mushrooms and certified reference materials (SRM 1570a spinach leaves) were digested in a temperature- and pressure-controlled analytical microwave oven. For their decomposition, about $0.5 \mathrm{~g}$ of material was treated with

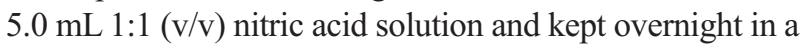
Teflon vessel. Afterward the Teflon vessel was closed and put into a pressurized digestion system. Thermal heating was carried out at $150^{\circ} \mathrm{C}$ for $8 \mathrm{~h}$. After cooling at room temperature these solutions were adjusted to $\mathrm{pH}$ with a $10 \%$ (w/v) sodium hydroxide solution and appropriate buffer solution. The final solution volume was completed at $50.0 \mathrm{~mL}$, and the developed biosorption method was applied to the samples. The concentrations of analytes in the samples were determined by AAS.

\section{Results and Discussion}

The chemistry of the metal ions, the structure and constituents of the cell wall, and the external conditions are very important for the biosorption of metals by microorganisms. Therefore, when evaluating the analytical procedure the following parameters such as sample $\mathrm{pH}$, sample volume, flow rates of sample and eluent, and the influence of other ions must be investigated and optimized initially.

\section{The Effect of $\mathrm{pH}$}

The $\mathrm{pH}$ of the sample solution played an important role in the ability of the column containing the KG9 strain immobilized on Amberlite XAD-4 to preconcentrate the studied metal ions. Different microorganisms exhibit different biosorption characteristics at a given $\mathrm{pH}$ because of differences in the cell wall composition. The solution $\mathrm{pH}$ influences both the cell wall metal binding sites and aqueous metal chemistry. Due to this important point, the effect of $\mathrm{pH}$ was investigated at the $\mathrm{pH}$ ranges of 2.0-8.0 with model solution, keeping the other parameters constant and by applying a general preconcentration procedure. The metal ions were then eluted by an appropriate eluent and determined by AAS. The optimum $\mathrm{pH}$ range was 6.08.0 for $\mathrm{Cd}, 5.0-7.0$ for $\mathrm{Cu}$, and 6.0-8.0 for $\mathrm{Ni}$.

The results given in Fig. 1 indicate that the cell surface becomes positively charged at low $\mathrm{pH}$ values, which decrease the interactions between metal ions and the functional groups on the cell wall, whereas the cell surface becomes negatively charged at high $\mathrm{pH}$ values, increasing the interactions until a maximum is reached at $\mathrm{pH}$ 6.0. It can also be seen that for $\mathrm{pH}$ values higher than the optimum value of 6.0, the retention decreases again due to the competition between the hydroxylated complexes of the metal and active sites of the cell. For avoiding precipitation of metals, high $\mathrm{pH}$ values were not preferable and the optimum $\mathrm{pH}$ was chosen as $\mathrm{pH} 6.0$ for all three metals.

\section{Effect of Sample Solution Flow Rates}

The retention of an element on an adsorbent also depends on the flow rate of the sample solution. Therefore, the effect of the flow rate of the sample solution on the recovery of the analytes was investigated under optimum 


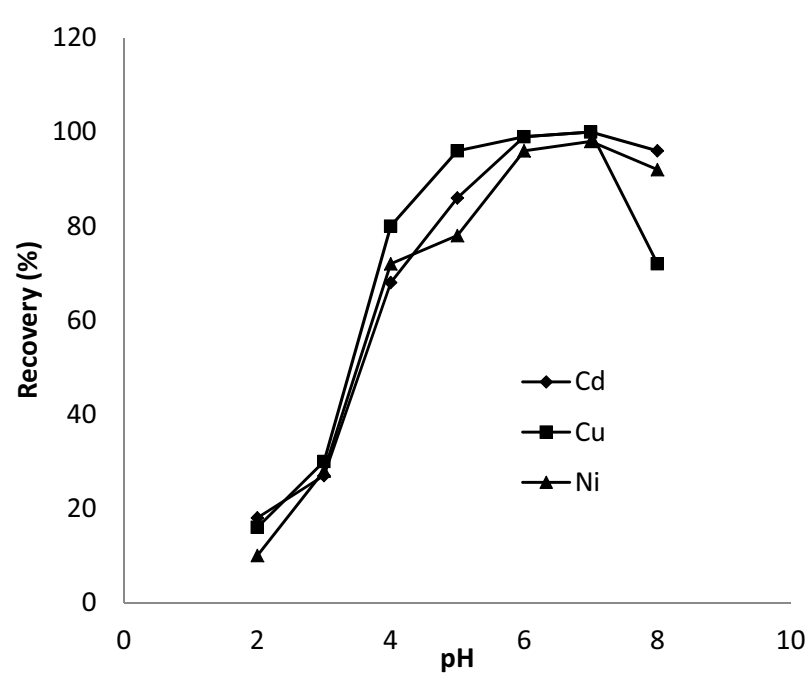

Fig. 1. Effect of $\mathrm{pH}$ on the recovery of cadmium, copper, and nickel by thermophilic haloalkalitolerant bacterial strain (KG9) immobilized on Amberlite XAD-4 resin.

conditions (pH, eluent type, etc.). For each metal ion, a set of solutions $(50 \mathrm{~mL})$ containing its $50 \mu \mathrm{g}$ were adjusted to the optimum $\mathrm{pH}$ value. In the proposed system, the sample solution was passed through the column with the flow rates adjusted in a range of 1.0-6.0 $\mathrm{mL} \cdot \mathrm{min}^{-1}$. As can be seen in Fig. 2, at flow rates greater than $2 \mathrm{~mL} / \mathrm{min}$ there was a decrease in the recovery of cadmium, copper, and nickel. The reason for this decrease is probably insufficient contact of the metal ions and the adsorbent to reach equilibrium. Therefore, all further studies were performed at $2 \mathrm{~mL} \cdot \mathrm{min}^{-1}$ flow rates for sample solutions.

The effect of the eluent flow rate in the step of desorption of the metals from minicolumn was also investigated.in the range of 1.0 to $6.0 \mathrm{~mL} \cdot \mathrm{min}^{-1}$. Above $3.0 \mathrm{~mL} \cdot \mathrm{min}^{-1}$, the recovery for cadmium, copper, and nickel was less than $95 \%$, as the metal ions combine strongly with adsorbent. The flow rate of the elution solution was $2 \mathrm{~mL} \cdot \mathrm{min}^{-1}$.

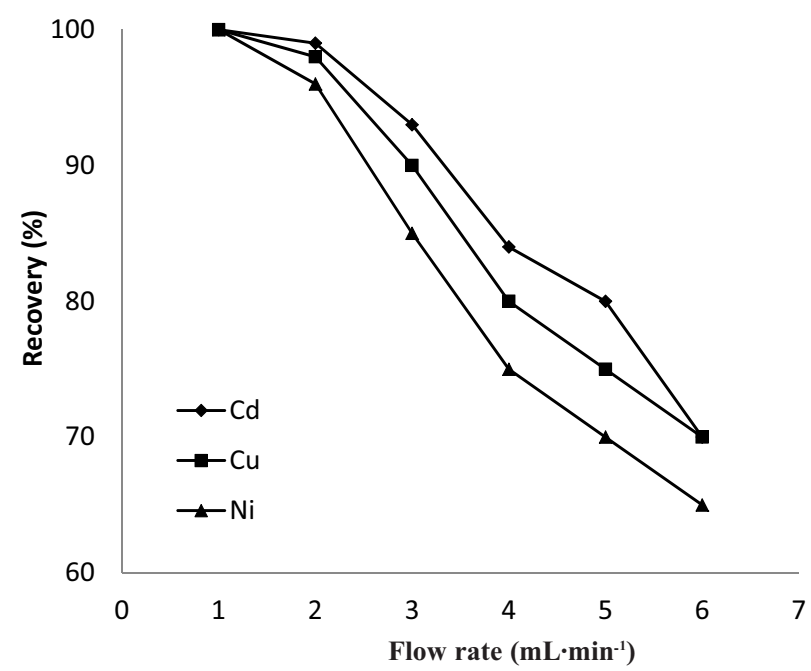

Fig. 2. Effect of sample solution flow rate on the recovery of cadmium, copper, and nickel by thermophilic haloalkalitolerant bacterial strain (KG9) immobilized on Amberlite XAD-4 resin.

\section{Effect of Adsorbent Amount}

The effect of the amount of KG9 strain immobilized on Amberlite XAD-4 resin on the sorption of metal ions at optimum $\mathrm{pH}$ was investigated in the range $100.0-500.0 \mathrm{mg}$. The results are shown in Fig. 3. It was found that above $100.0 \mathrm{mg}$ of adsorbent the recovery of cadmium, copper, and nickel was gradually increased. The highest recoveries were obtained when the resin amount was $300.0 \mathrm{mg}$. However, above $300.0 \mathrm{mg}$ there was not any change in the recoveries of $\mathrm{Cd}^{+2}, \mathrm{Cu}^{+2}$, and $\mathrm{Ni}^{+2}$. Therefore, $300 \mathrm{mg}$ adsorbent was used for cadmium, copper, and nickel.

\section{Effect of Type and Volume of Elution Solutions}

The other important factor that affects the preconcentration procedure is the type, volume, and concentration of the eluent used for the removel of metal ions from the solid XAD-4 loaded with bacterial strain KG9. The concentration of the acid used as an eluent must be the lowest possible level in order to prevent degradation of the biomass. The different concentrations of nitric acid and hydrochloric acid were tested to remove the bound metal ions from the bacterial biomass loaded on the column. As shown in Table 1, $10.0 \mathrm{~mL}$ of $0.5 \mathrm{~mol} \cdot \mathrm{L}^{-1} \mathrm{HCl}$ solution was found to be satisfactory (recovery $>95 \%$ ) for cadmium, copper, and nickel.

\section{Effect of Sample Solution}

The effect of sample volume on the elution of cadmium, copper, and nickel was studied by taking different volumes of the water samples in the range $100-1000 \mathrm{~mL}$. It was found that both cadmium, copper, and nickel could be recovered quantitatively ( $>95 \%$ ) up to $500 \mathrm{~mL}$ of the sample solution. At higher sample volumes, the recoveries decreased gradually with increasing volume of sample solution. Hence, $500 \mathrm{~mL}$ sample solution was chosen for the present study and the results are shown in Fig. 4.

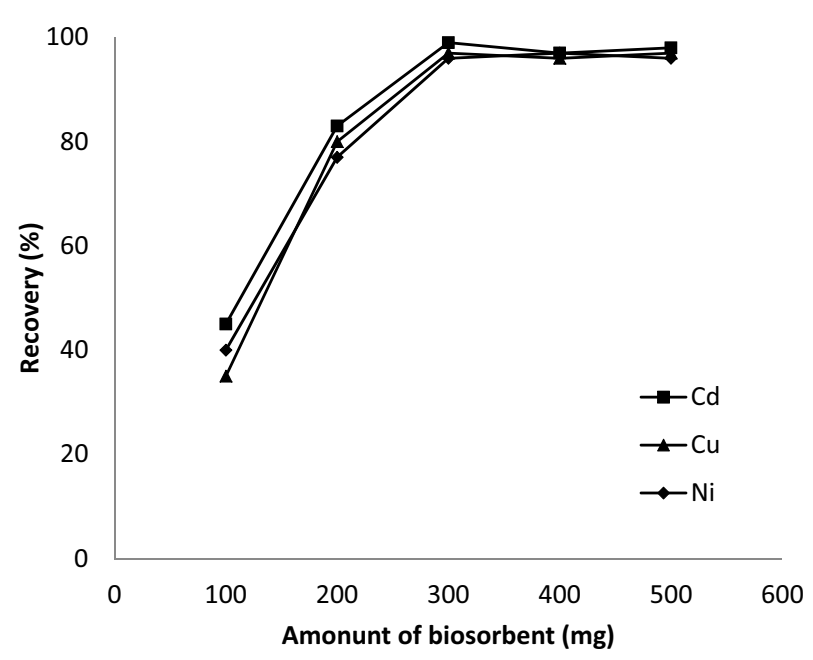

Fig. 3. Effect of amount of adsorbent on the recovery of cadmium, copper, and nickel by thermophilic haloalkalitolerant bacterial strain (KG9) immobilized on Amberlite XAD-4 resin. 
Table 1. Effect of type and volume of elution solutions on the recovery of $\mathrm{Cd}^{+2}, \mathrm{Cu}^{+2}$, and $\mathrm{Ni}^{+2}$.

\begin{tabular}{|c|c|c|c|c|}
\hline $\begin{array}{c}\text { Concentration and } \\
\text { type of eluent }\end{array}$ & $\begin{array}{c}\text { Volume of } \\
\text { eluent }(\mathrm{mL})\end{array}$ & $\mathrm{Cd}$ & $\mathrm{Cu}$ & $\mathrm{Ni}$ \\
\hline $0.25 \mathrm{~mol} \cdot \mathrm{L}^{-1} \mathrm{HNO}_{3}$ & 3.0 & $64 \pm 2$ & $67 \pm 3$ & $60 \pm 2$ \\
\hline $0.50 \mathrm{~mol} \cdot \mathrm{L}^{-1} \mathrm{HNO}_{3}$ & 3.0 & $76 \pm 1$ & $78 \pm 2$ & $71 \pm 1$ \\
\hline $1.00 \mathrm{~mol} \cdot \mathrm{L}^{-1} \mathrm{HNO}_{3}$ & 3.0 & $79 \pm 2$ & $82 \pm 2$ & $76 \pm 2$ \\
\hline $0.25 \mathrm{~mol} \cdot \mathrm{L}^{-1} \mathrm{HNO}_{3}$ & 5.0 & $71 \pm 1$ & $80 \pm 2$ & $66 \pm 1$ \\
\hline $0.50 \mathrm{~mol} \cdot \mathrm{L}^{-1} \mathrm{HNO}_{3}$ & 5.0 & $83 \pm 1$ & $86 \pm 1$ & $70 \pm 2$ \\
\hline $1.00 \mathrm{~mol} \cdot \mathrm{L}^{-1} \mathrm{HNO} 3$ & 5.0 & $92 \pm 1$ & $87 \pm 2$ & $82 \pm 1$ \\
\hline $0.25 \mathrm{~mol} \cdot \mathrm{L}^{-1} \mathrm{HCl}$ & 3.0 & $67 \pm 2$ & $81 \pm 1$ & $78 \pm 3$ \\
\hline $0.50 \mathrm{~mol} \cdot \mathrm{L}^{-1} \mathrm{HCl}$ & 3.0 & $90 \pm 1$ & $89 \pm 2$ & $84 \pm 2$ \\
\hline $1.00 \mathrm{~mol} \cdot \mathrm{L}^{-1} \mathrm{HCl}$ & 3.0 & $96 \pm 2$ & $92 \pm 1$ & $90 \pm 1$ \\
\hline $0.25 \mathrm{~mol} \cdot \mathrm{L}^{-1} \mathrm{HCl}$ & 5.0 & $82 \pm 1$ & $84 \pm 2$ & $80 \pm 1$ \\
\hline $0.50 \mathrm{~mol} \cdot \mathrm{L}^{-1} \mathrm{HCl}$ & 5.0 & $98 \pm 2$ & $97 \pm 2$ & $96 \pm 2$ \\
\hline $1.00 \mathrm{~mol} \cdot \mathrm{L}^{-1} \mathrm{HCl}$ & 5.0 & $98 \pm 2$ & $99 \pm 1$ & $96 \pm 1$ \\
\hline
\end{tabular}

\section{Effect of Column Reuse}

In order to examine the long-term stability of the biosorbent, the metal ions were sorbed and desorbed several times using a solution $(50 \mathrm{~mL})$ having a concentration of 5-50 $\mu \mathrm{g} \cdot \mathrm{mL}^{-1}$ under optimum experimental conditions. The column could be used with good precision and quantitative recovery $(>95 \%)$ for 25 cycles. After 25 cycles, there was a reduction in the recovery of ions. Therefore, repeated use of the biosorbent is feasible.

\section{Adsorption Capacites}

The capacity of the adsorbent is an important factor because it determines how much adsorbent is required to quantitatively remove a specific amount of metal ions from

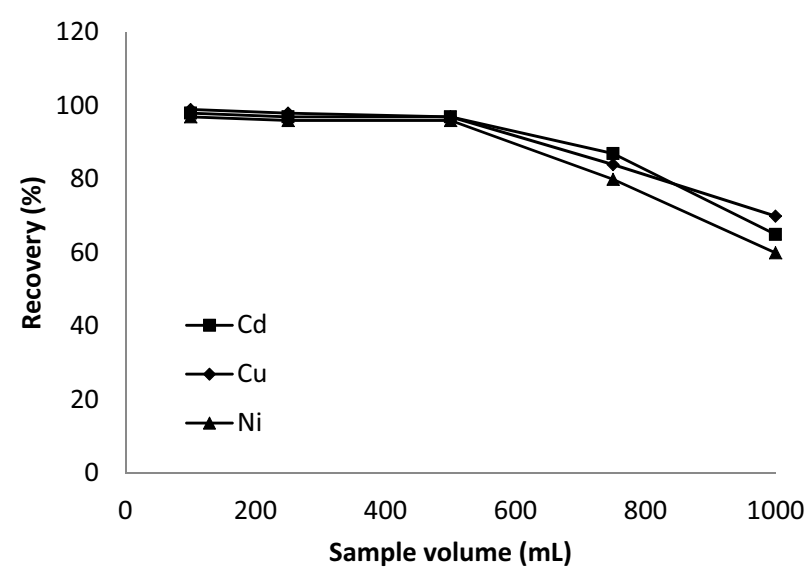

Fig. 4. Effect of sample solution volumes on the recovery of cadmium, copper, and nickel by thermophilic haloalkalitolerant bacterial strain (KG9) immobilized on Amberlite XAD-4 resin. the solutions. About $300 \mathrm{mg}$ of the biosorbent was equilibrated with $100 \mathrm{~mL}$ of $50.0 \mathrm{mg} \cdot \mathrm{L}^{-1}$ metal ion $(\mathrm{Cd}, \mathrm{Cu}, \mathrm{Ni})$ at their optimum $\mathrm{pH}$. After shaking for $4 \mathrm{~h}$ in separate flasks, the mixture was filtered by gravity. The loading capacity of the biosorbent for each metal ion was calculated from the difference between the metal ion concentrations before and after desorption. The capacity of biosorbent was found as 22.7 for $\mathrm{Cd}(\mathrm{II}), 61.1 \mathrm{for} \mathrm{Cu}(\mathrm{II})$, and $33.4 \mu \mathrm{mol} \cdot \mathrm{g}^{-1}$ for $\mathrm{Ni}(\mathrm{II})$.

\section{Effect of Foreign Ions}

The presence of other ions in solution is known to affect the biosorption of the derived metal, so it plays an important role in the selection of an appropriate biosorbent. The cations compete for available binding sites on the biosorbent, or they may enhance biosorption by taking part in the formation of coordination compounds or complexes for the adsorption of a particular metal. In the present study, the influences of some cation and anions on the recoveries of the metal ions by the bacterial strain KG9 loaded onto Amberlite XAD-4 in the column were investigated. The results are given in Table 2 . The recovery values for cadmium $\left(25 \mu \mathrm{g} \cdot \mathrm{L}^{-1}\right)$, copper $\left(50 \mu \mathrm{g} \cdot \mathrm{L}^{-1}\right)$, and nickel $\left(100 \mu \mathrm{g} \cdot \mathrm{L}^{-1}\right)$ from the biosorbent column were not affected from the solution containing high concentrations of matrix ions. These results indicate that the common constituents of natural water and mushroom samples do not affect the sorption efficiency of this biosorbent when present at their normal concentration levels.

Table 2. Effect of other ions on the recoveries of $\mathrm{Cd}^{+2}\left(25 \mu \mathrm{g} \cdot \mathrm{L}^{-1}\right)$, $\mathrm{Cu}^{+2}\left(50 \mu \mathrm{g} \cdot \mathrm{L}^{-1}\right)$, and $\mathrm{Ni}^{+2}\left(100 \mu \mathrm{g} \cdot \mathrm{L}^{-1}\right)$.

\begin{tabular}{|c|c|c|c|c|}
\hline \multirow{2}{*}{ Ion } & \multirow{2}{*}{$\begin{array}{c}\text { Concentration } \\
\left(\mathrm{mg} \cdot \mathrm{L}^{-1}\right)\end{array}$} & \multicolumn{3}{|c|}{ Recovery $(\%)$} \\
\cline { 3 - 5 } & 2500 & $98 \pm 3$ & $97 \pm 2$ & $99 \pm 1$ \\
\hline $\mathrm{Na}^{+}$ & 1000 & $97 \pm 2$ & $96 \pm 1$ & $98 \pm 2$ \\
\hline $\mathrm{K}^{+}$ & 1000 & $94 \pm 4$ & $95 \pm 3$ & $95 \pm 2$ \\
\hline $\mathrm{Ca}^{+2}$ & 1000 & $95 \pm 3$ & $98 \pm 2$ & $97 \pm 2$ \\
\hline $\mathrm{Mg}^{+2}$ & 2500 & $97 \pm 2$ & $98 \pm 2$ & $94 \pm 3$ \\
\hline $\mathrm{Cl}^{-}$ & 1000 & $97 \pm 3$ & $100 \pm 1$ & $96 \pm 2$ \\
\hline $\mathrm{F}^{-}$ & 2500 & $97 \pm 2$ & $96 \pm 2$ & $95 \pm 3$ \\
\hline $\mathrm{NO}_{3}^{-}$ & 2000 & $99 \pm 2$ & $101 \pm 3$ & $96 \pm 2$ \\
\hline $\mathrm{SO}_{4}^{-2}$ & 2.0 & $98 \pm 2$ & $96 \pm 3$ & $97 \pm 2$ \\
\hline $\mathrm{Mn}^{+2}$ & 1.0 & - & $96 \pm 2$ & $96 \pm 3$ \\
\hline $\mathrm{Cd}^{+2}$ & 2.0 & $96 \pm 2$ & $95 \pm 3$ & $94 \pm 2$ \\
\hline $\mathrm{Fe}^{+2}$ & 2.0 & $97 \pm 2$ & $98 \pm 3$ & $96 \pm 2$ \\
\hline $\mathrm{Zn}^{+2}$ & 2.0 & $99 \pm 1$ & - & $97 \pm 2$ \\
\hline $\mathrm{Cu}^{+2}$ & 2.0 & $95 \pm 3$ & $96 \pm 2$ & - \\
\hline $\mathrm{Ni}^{+2}$ & & & & \\
\hline
\end{tabular}


Table 3. Results obtained for the certified reference materials analyzed after application of the presented procedure.

\begin{tabular}{|l|c|c|c|c|c|c|c|c|c|}
\hline \multirow{2}{*}{ Sample } & \multicolumn{3}{|c|}{$\mathrm{Cd}^{+2}$} & \multicolumn{3}{c|}{$\mathrm{Cu}^{+2}$} & \multicolumn{3}{c|}{$\mathrm{Ni}^{+2}$} \\
\cline { 2 - 11 } & $\begin{array}{c}\text { Certified } \\
\text { value }\end{array}$ & Found & $\begin{array}{c}\text { Relative } \\
\text { error }(\%)\end{array}$ & $\begin{array}{c}\text { Certified } \\
\text { value }\end{array}$ & Found & $\begin{array}{c}\text { Relative } \\
\text { error }(\%)\end{array}$ & $\begin{array}{c}\text { Certified } \\
\text { value }\end{array}$ & Found & $\begin{array}{c}\text { Relative } \\
\text { error }(\%)\end{array}$ \\
\hline $\begin{array}{l}\text { NRCC-SLTS4 Riverine } \\
\text { water (mg.L-1) }\end{array}$ & 0.0012 & BDL & - & 1.81 & $1.78 \pm 0.003$ & 98 & 0.67 & $0.64 \pm 0.03$ & 95 \\
\hline $\begin{array}{l}\text { SRM1570a Spinach } \\
\text { leaves (mg/kg) }\end{array}$ & 1.52 & $1.49 \pm 0.003$ & 98 & 4.70 & $4.65 \pm 0.12$ & 99 & 1.59 & $1.54 \pm 0.04$ & 97 \\
\hline
\end{tabular}

$\mathrm{BDL}$ - below the detection limit

Table 4. Concentrations of metal ions in real samples.

\begin{tabular}{|c|c|c|c|c|c|c|c|c|c|}
\hline \multirow[b]{2}{*}{ Sample } & \multicolumn{3}{|c|}{ Cadmium amount $\left(\mathrm{mg} \cdot \mathrm{L}^{-1}\right)$} & \multicolumn{3}{|c|}{ Copper amount $\left(\mathrm{mg} \cdot \mathrm{L}^{-1}\right)$} & \multicolumn{3}{|c|}{ Nickel amount $\left(\mathrm{mg} \cdot \mathrm{L}^{-1}\right)$} \\
\hline & Added & Found* & $\begin{array}{c}\text { Recovery } \\
(\%)\end{array}$ & Added & Found* & $\begin{array}{c}\text { Recovery } \\
(\%)\end{array}$ & Added & Found* & $\begin{array}{c}\text { Recovery } \\
(\%)\end{array}$ \\
\hline \multirow{3}{*}{$\begin{array}{l}\text { River water } \\
\left(\mathrm{mg} \cdot \mathrm{L}^{-1}\right)\end{array}$} & 0.0 & $24.27 \pm .08$ & - & 0.0 & $38.4 \pm 0.9$ & - & 0.0 & $63.6 \pm 1.1$ & - \\
\hline & 5.0 & $28.52 \pm 1.2$ & 97 & 5.0 & $42.6 \pm 1.1$ & 98 & 5.0 & $68.2 \pm 0.7$ & 99 \\
\hline & 10.0 & $35.38 \pm 0.9$ & 103 & 10.0 & $49.2 \pm 0.8$ & 101 & 10.0 & $71.4 \pm 0.9$ & 97 \\
\hline \multirow{3}{*}{$\begin{array}{l}\text { Drinking water } \\
\text { from Diyarbakir } \\
\text { city } \\
\left(\mathrm{mg} \cdot \mathrm{L}^{-1}\right)\end{array}$} & 0.0 & $<\mathrm{LOD}$ & - & 0.0 & $<\mathrm{LOD}$ & - & 0.0 & $<\mathrm{LOD}$ & - \\
\hline & 5.0 & $4.76 \pm 0.11$ & 95 & 5.0 & $5.23 \pm 0.2$ & 105 & 5.0 & $5.18 \pm 0.2$ & 104 \\
\hline & 10.0 & $9.82 \pm 0.2$ & 98 & 10.0 & $10.42 \pm 0.3$ & 104 & 10.0 & $9.42 \pm 0.3$ & 94 \\
\hline \multirow{3}{*}{$\begin{array}{l}\text { Mushroom } \\
\text { (mg/kg } \\
\text { dry matter) }\end{array}$} & 0.0 & $0.85 \pm 0.06$ & - & 0.0 & $8.32 \pm 0.3$ & - & 0.0 & $0.82 \pm 0.1$ & - \\
\hline & 5.0 & $5.8 \pm 0.1$ & 101 & 5.0 & $12.96 \pm 1.1$ & 97 & 5.0 & $5.63 \pm 0.12$ & 96 \\
\hline & 10.0 & $10.54 \pm 0.1$ & 98 & 10.0 & $18.67 \pm 0.8$ & 102 & 10.0 & $10.72 \pm 0.1$ & 101 \\
\hline
\end{tabular}

*Confidence interval 95\%

LOD - limit of detection

\section{Detection Limits}

The limits of detection (LOD) of the proposed preconcentration method for the determination of heavy metals were obtained by passing $50 \mathrm{~mL}$ of a blank solution from the column under the optimal experimental conditions by using a regression equation for each analyte. The detection limits $(n=20$, blank $\pm 3 s$, where $s$ is the standart deviation of the blank), for $\mathrm{Cd}(\mathrm{II}), \mathrm{Cu}(\mathrm{II})$, and $\mathrm{Ni}(\mathrm{II})$ were found to be $0.42,0.54$, and $1.24 \mu \mathrm{g} \cdot \mathrm{L}^{-1}$, respectively.

The preconcentration factors that were calculated from the ratio of highest sample volume obtained quantitative recoveries to $5 \mathrm{~mL}$ final volume. The preconcentration factor was found as 100 for each metal ion.

\section{Applications}

The method presented was checked for analyzing NRCC-SLRS-4 riverine water $(50 \mathrm{~mL})$ and SRM1570a spinach leaves certified reference materials for cadmium, copper, and nickel ions. The results are given in Table 3. The certified and observed values for certified reference materials were in good agreement with the certified values of SRMs. The relative errors were at acceptable levels for quantitative trace analysis. These results also indicate that the developed method is not affected by potential interfer- ence from the major matrix elements of the analyzed reference materials.

In order to check the applicability of the proposed method, Tigris river and Diyarbakir drinking water samples, as well as mushrooms, were analyzed as real samples. Cadmium, copper, and nickel were determined in the samples after the separation and enrichment of metal ions by SPE. An appropriate volume of sample solutions was adjusted to the optimum $\mathrm{pH}$ and subjected to the recommended column procedure for the preconcentration and determination of metal ions. The results are reported in Table 4 with confidence interval for $95 \%$ confidence level show the applicability of the proposed method for water and vegetable analysis.

\section{Conclusion}

The use of microorganisms as biosorbent materials for metals has become a useful alternative to other preconcentration methods due to their higher recoveries, economical advantages, simplicity, and environmental safety. A newly isolated thermophilic haloalkalitolerant bacterial strain (KG9) was found to be a new effective biosorbent for the enrichment of $\mathrm{Cd}(\mathrm{II}), \mathrm{Cu}(\mathrm{II})$, and $\mathrm{Ni}(\mathrm{II})$ prior to FAAS. The biosorbent was used at least 25 times and there is not 
Table 5. Comparative data about biosorption of heavy metal ions on microorganisms immobilised on various support materials.

\begin{tabular}{|c|c|c|c|c|c|c|c|}
\hline Elements & Sample & Immobilized microorganism & $\begin{array}{l}\text { Detection } \\
\text { system }\end{array}$ & $\mathrm{PF}$ & LOD & Capacity & Referances \\
\hline $\begin{array}{l}\mathrm{Fe}^{+3}, \mathrm{Co}^{+2} \\
\mathrm{Mn}^{+2}, \mathrm{Cr}^{+3}\end{array}$ & Alloy and water & $\begin{array}{l}\text { A. tumefacients immobilized } \\
\text { on Amberlite XAD-4 }\end{array}$ & FAAS & 25 & $2.8-3.6 \mu \mathrm{g} \cdot \mathrm{L}^{-1}$ & $1.2-1.7 \mathrm{mg} \cdot \mathrm{g}^{-1}$ & [38] \\
\hline $\begin{array}{l}\mathrm{Cu}^{+2}, \mathrm{Zn}^{+2} \\
\mathrm{Cd}^{+2}\end{array}$ & $\begin{array}{l}\text { Vegetable and dam, } \\
\text { lake and tap waters }\end{array}$ & $\begin{array}{l}\text { S. carlsbergensis immobilized } \\
\text { on silica gel }\end{array}$ & FAAS & 50 & $1.14-1.66 \mathrm{ng} \cdot \mathrm{mL}^{-1}$ & - & [38] \\
\hline $\begin{array}{l}\mathrm{Cu}^{+2}, \mathrm{~Pb}^{+2} \\
\mathrm{Zn}^{+2}, \mathrm{Fe}^{+3} \\
\mathrm{Ni}^{+2}, \mathrm{Co}^{+2}\end{array}$ & $\begin{array}{l}\text { Water, dust, and black } \\
\text { tea }\end{array}$ & $\begin{array}{l}\text { Aspergilus fumigatus } \\
\text { immobilized } \\
\text { on Diaion HP-2MG }\end{array}$ & FAAS & 50 & $0.30-0.72 \mu \mathrm{g} \cdot \mathrm{L}^{-1}$ & $4.4-8.05 \mathrm{mg} \cdot \mathrm{g}^{-1}$ & [26] \\
\hline $\begin{array}{l}\mathrm{Cu}^{+2}, \mathrm{Zn}^{+2} \\
\mathrm{~Pb}^{+2}\end{array}$ & Waters and vegetables & $\begin{array}{l}\text { P. digitatum immobilized } \\
\text { on pumice stone }\end{array}$ & FAAS & 50 & $1.3-5.8 \mu \mathrm{g} \cdot \mathrm{L}^{-1}$ & - & {$[38]$} \\
\hline $\begin{array}{l}\mathrm{Cu}^{+2}, \mathrm{Zn}^{+2} \\
\mathrm{Fe}^{+3}, \mathrm{Ni}^{+2} \\
\mathrm{Cd}^{+2}\end{array}$ & Alloys & $\begin{array}{l}\text { Escherichia coli immobilized } \\
\text { on sepolite }\end{array}$ & FAAS & 50 & $67-95 \mathrm{ng} \cdot \mathrm{mL}^{-1}$ & $4.2-9.9 \mathrm{mg} \cdot \mathrm{g}^{-1}$ & [25] \\
\hline $\mathrm{Cu}^{+2}, \mathrm{Cd}^{+2}$ & $\begin{array}{l}\text { River and water } \\
\text { systems }\end{array}$ & $\begin{array}{l}\text { Bacillus subtilis immobilized } \\
\text { on Amberlite XAD-4 }\end{array}$ & FAAS & 50 & - & $1.88-3.92 \mathrm{mg} \cdot \mathrm{g}^{-1}$ & {$[5]$} \\
\hline $\begin{array}{l}\mathrm{Cu}^{+2}, \mathrm{Zn}^{+2} \\
\mathrm{Fe}^{+3}\end{array}$ & $\begin{array}{l}\text { A multivitamin tablet, } \\
\text { Dialysis solutions, } \\
\text { Natural waters and } \\
\text { some food samples }\end{array}$ & $\begin{array}{l}\text { Bacillus thuringiensis } \\
\text { israelensis loaded } \\
\text { on Dowex optipore V-493 }\end{array}$ & FAAS & 37 & $0.14-2.01 \mu \mathrm{g} \cdot \mathrm{L}^{-1}$ & $2.55-4.05 \mathrm{mg} \cdot \mathrm{g}^{-1}$ & [39] \\
\hline $\begin{array}{l}\mathrm{Cd}^{+2}, \mathrm{Cu}^{+2} \\
\mathrm{Ni}^{+2}\end{array}$ & $\begin{array}{l}\text { River water, drinking } \\
\text { water and mushroom }\end{array}$ & $\begin{array}{l}\text { Thermophilic haloalkalitoler- } \\
\text { ant Bacillus licheniformis } \\
\text { strain (KG9) Immobilized on } \\
\text { Amberlite XAD-4 }\end{array}$ & FAAS & 100 & $0.45-1.24 \mu \mathrm{g} \cdot \mathrm{L}^{-1}$ & $1.96-3.88 \mathrm{mg} \cdot \mathrm{g}^{-1}$ & $\begin{array}{l}\text { Present } \\
\text { work }\end{array}$ \\
\hline
\end{tabular}

$\mathrm{PF}$ - preconcentration factor, LOD - limit of detection, FAAS - flame atomic absorption spectrometry

any loss in its adsorption properties. Such sorbents can be stored for a long time. The analytical results for certified reference materials were in good agreement with the reference values. The comparisons of the presented procedure with the other procedures given in the literature are given in Table 5. The preconcentration factors calculated for the analytes were found to be superior to those in the literature.

\section{References}

1. LEMOS V.A., BALIZA P.X. Amberlite XAD-2 functionalized with 2-aminothiophenol as a new sorbent for on-line preconcentration of cadmium and copper. Talanta 67, 564 , 2005.

2. OZDEMIR S., GUL-GUVEN R. KILINÇ E., DOGRU M. ERDOĞAN S. Preconcentration of cadmium and nickel using the bioadsorbent Geobacillus thermoleovorans subsp. stromboliensis immobilized on Amberlite XAD-4. Microchimica Acta 169, 79, 2010.

3. BAYTAK S., TURKER A.R. The use of Agrobacterium tumefacients immobilized on Amberlite XAD-4 as a new biosorbent for the column preconcentration of iron(III), cobalt(II), manganese(II) and chromium(III). Talanta $\mathbf{6 5}$, 938, 2005

4. SOYLAK M., YILMAZ E., GHAEDİ M., MONTAZEROZOHORİ M. Solid phase extraction on multiwalled carbon nanotubes and flame atomic absorption spectrometry combination for determination of some metal ions in environmental and food samples. Toxicol. Environ. Chem. 93, 873, 2011.
5. DOGRU M., GUL-GUVEN R., ERDOGAN S. The use of Bacillus subtilis immobilized on Amberlite XAD-4 as a new biosorbent in trace metal determination. J. Hazard. Mater. 149, 166, 2007.

6. TUZEN M. SOYLAK M. Column solid-phase extraction of nickel and silver in environmental samples prior to their flame atomic absorption spectrometric determinations. J. Hazard. Mater. 164, 1428, 2009.

7. CAMEL V. Solid phase extraction of trace elements. Spectrochim. Acta B 58, 1177, 2003.

8. LEMOS V. A., NOVAS C.G., DA LIMA S. A., VIEİRA D.R. Flow injection preconcentration system using a new functionalized resin for determination of cadmium and nickel in tobacco samples. J. Hazard. Mater. 155, 128, 2008.

9. GHAEDI M., NIKNAM K., TAHERI K., HASAINIAN H., SOYLAK M. Flame atomic absorption spectrometric determination of copper,zinc and manganese after solid-phase extraction using 2,6-dichlorophenyl-3,3-bis(indoly) methane loaded on Amberlite XAD-16. Food Chem. Toxicol. 48, 891, 2010.

10. OZDEMIR S., KILINÇ E., ERDOGAN S. Bacillus sp. immobilized on Amberlite XAD-4 resin as a biosorbent for solid phase extraction of thorium prior to UV-vis spectrometry determination. Microchimica Acta 171, 275, 2010.

11. BAYTAK S., ZEREEN F., ARSLAN Z. Preconcentration of trace elements from water samples on a minicolumn of yeast (Yamadazyma spartinae) immobilized $\mathrm{TiO}_{2}$ nanoparticles for determination by ICP-AES. Talanta 84, 319, 2011.

12. ERDOGAN S., BAYSAL A., AKBA O., HAMAMCI C. Interaction of metals with humic acid isolated from oxidized coal. Pol. J. Environ. Stud. 16, 671, 2007. 
13. HAMAMCI C., HOSGOREN H., ERDOGAN S. The solvent extraction of alkali metal picrates with 4,13-N,N'dibenzyl-4,13-diaza-18-crown-6. Talanta 47, 229, 1998.

14. DİNIZ M.C.T., FATIBBELLO O., ROHWEDDER J.J.R. An qutomated system for liquid-liquid extraction based on a new micro-batch extraction chamber with on-line detection:Preconcentration and determination of copper(II) Analytica Chimica Acta 525, 281, 2004.

15. ÇITAK D., TUZEN M., SOYLAK M. Simultaneous coprecipitation of lead, cobalt, copper, cadmium, iron and nickel in food samples with zirconium(IV) hydroxide prior to their flame atomic absorption spectrometric determination. Food Chem. Toxicol. 47, 2302, 2009.

16. DABROWSKI A., HUBICKI Z., PODKOSCIEINY P., ROBENS E. Selective removal of the heavy ions from waters and industrial wastewaters by ion-exchange method. Chemosphere 56, 91, 2004.

17. VERMA V.K., TEWARİ S., RAİ J.P.N. Ion exchange during heavy metal biosorption from aqueous solution by dried biomass of macrophytes. Bioresource Technol. 99, 1932, 2008.

18. LIUU F., Lİ L., LİNG P., JiNG X., Lİ C., Lİ A., YOU X. Interaction mechanism of aqueous heavy metals onto a newly synthesized IDA-chelating resin: Isotherms, thermodynamics and kinetics. Chem. Eng. J. 173, 106, 2011.

19. GODLEWSKA-ZYLKİEWICZ B. Microorganisms in inorganic chemical analysis. Analytical and Bioanalytical Chemistry 384, 114, 2006.

20. TUZEN M., SOYLAK M. Biosorption of aluminum on Pseudomonas aeruginosa loaded on Chromosorb 106 prior to its graphite furnace atomic absorption spectrometric determination. J. Hazard. Mater. 154, 519, 2008.

21. VIJJAYARAGHAVAN K., YEOUNG-SANG Y. Bacterial bio-sorbents and biosorption. Biotechnol. Adv. 26, 266, 2008.

22. BAKIRCIOGLU D., UCAR G., BAKIRCIOGLU KURTULUS Y. Coliform bacteria immobilized on titanium dioxide nanoparticles as a biosorbent for trace lead preconcentration followed by atomic absorption spectrometric determination. Microchimica Acta 174, 367, 2011

23. YANG G., FEN W., LEI C., XIAO W., SUN H. Study on solid phase extraction and graphite furnace atomic absorption spectrometry for the determination of nickel, silver, cobalt, copper, cadmium and lead with MCI GEL CHP 20Y as sorbent. J. Hazard. Mater. 162, 44, 2009.

24. PACHECO P.H., GIL R.A., CERUTTİ S.E., SMICHOWSKİ P., MARTINEZ L.D. Biosorption: a new rise for elemental solid phase extraction methods. Talanta 85, 2290, 2011.

25. BAĞ H., TURKER A.R., LALE M., TUNCELİ A. Separation and speciation of $\mathrm{Cr}(\mathrm{III})$ and $\mathrm{Cr}(\mathrm{VI})$ with Saccharomyces cerevisiae immobilized on sepiolite and determination of both species in water by FAAS. Talanta. 51, 895, 2000.

26. SOYLAK M., TUZEN M., MENDİL D., TURKEKUL İ. Biosorption of heavy metals on Aspergillus fumigatus immobilized diaion HP-2MG resin for their atomic absorption spectrometric determinations. Talanta 70, 1129, 2006.

27. ALLER A.J., CASTRO M.A. Live bacterial cells as analytical tools for speciation analysis: Hypothetical or practical? TRAC-Trend. Anal. Chem. 25, 887, 2006.

28. BAYSAL Z., ÇINAR E., BULUT Y., ALKAN H., DOGRU $M$. Equilibrium and thermodynamic studies on biosorption of $\mathrm{Pb}$ (II) onto Candida albicans biomass. J. Hazard. Mater. 161, 62, 2009.

29. BAYTAK S., KENDÜZLER E., TURKER A.R., GÖK N. Penicillium digitatum immobilized on pumice stone as a new solid phase extractor for preconcentration and/or separation of trace metals in environmental samples. J. Hazard. Mater. 153, 975, 2008.

30. VEGLIO F., BEOLCHINI F. Removal of metals by biosorption: a review. Hydrometallurgy 44, 301, 1997.

31. TUNÇELİ A., BAĞ H., TÜRKER A.R. Application of ram horn powder (RHP) in preconcentration and determination of copper in various samples by flame atomic absorption spectrometry fresenius. J. Anal. Chem. 371, 1134, 2001.

32. CUİ Y., CHANG X., ZHU X., JİANG N., HU Z., LİAN N. Nanometer $\mathrm{SiO}_{2}$ modified with 5-sulfosalicylic acid as selective solid-phase extractant for Fe(III) determination by ICP-AES from biological and natural water samples. Microchem. J. 86, 23, 2007.

33. Qİ W.T., MU J., YU W.T., XIE Y.B., WANG W., MA X.J. Behavior of microbial growth and metabolism in alginatechitosan-alginate (ACA) microcapsules. Enzyme Microb. Tech. 38, 697, 2006.

34. OZDEMIR G., CEYLAN N., MANAV E. Utilization of an exopolysaccharide produced by Chryseomonas luteola TEM05 in alginate beads for adsorption of cadmium and cobalt ions. Bioresource Technol. 96, 1677, 2005.

35. GURNANI V., SINGH A.K., VENKATARAMANI B. Cellulose based macromolecular chelator having pyrocatechol as an anchored ligand: synthesis and applications as metal extractant prior to their determination by flame atomic absorption spectrometry. Talanta 61, 889, 2003.

36. GURNANI V., SINGH A.K., VENKATARAMANI B. Cellulose functionalized with 8-hydroxyquinoline: new method of synthesis and applications as a solid phase extractant in the determination of metal ions by flame atomic absorption spectrometry. Anal. Chim. Acta 485, 221, 2003.

37. KOCAOBA S., ARISOY M. The use of a white rot fungi (Pleurotus ostreatus) immobilized on Amberlite XAD-4 as a new biosorbent in trace metal determination. Bioresource Technol. 102, 8035, 2011.

38. BAYTAK S., KENDÜZLER E., TURKER A.R. Separation/ preconcentration by yeast (Saccharomyces carlsbergensis) immobilized on silica gel 60 of some trace metals in various samples. Separ. Sci. Technol. 41, 3449, 2006.

39. TUZEN M., MELEK E., SOYLAK M. Solid-phase extraction of copper,iron and zinc ions on Bacillus thuringiensis israelensis loaded on Dowex optipore V-493. J. Hazard. Mater. 159, 335, 2008. 